\title{
Representation of Culture, Gender and Identity: An Analysis of Stella Kon's Emily of Emerald Hill
}

\author{
Ong Cheng Teik
}

\begin{abstract}
The immense popularity of the monodrama Emily of Emerald Hill by Singaporean playwright Stella Kon hinges on a multiplicity of factors from the successful and nostalgic re-enactment of the glorious days of the Peranakan (Straits-born) Chinese in Singapore to the realistic portrayal of a Peranakan Chinese matriarch and protagonist Emily. It is the latter that this study seeks to interrogate the play to analyse the construction of the various female roles and identities Emily assumes from that of a daughter to a daughter-in-law, a wife, a mother and a Peranakan Chinese matriarch. Such realistic portrayal of a multidimensional character together with the resonance of the Peranakan tradition relived in the play endear her to the audience from Malaysia and Singapore that have a sizeable Peranakan Chinese community. In the analysis, this multidisciplinary study straddles and draws on insights from the fields of sociology, post-structuralism, Confucianism and psychoanalysis in its attempt to better understand the psyche and motivation behind Emily's skilful and triumphant negotiation with patriarchy reminiscent of the bygone days of the Peranakan Chinese community that privileged sons over daughters.
\end{abstract}

Index Terms-Confucianism, culture, female identities and roles, gender, patriarchy, Peranakan Chinese.

\section{INTRODUCTION}

The objective of this paper is to examine how culture, gender and identity are represented in Stella Kon's monodrama Emily of Emerald Hill, with particular reference to the roles portrayed by the protagonist Emily. In relation to this, the writer attempts an analysis of the multiple female gendered identities and roles dictated by the Confucian patriarchal belief system as observed by Emily’s Peranakan Chinese community.

In contrast to biological sex, the female gender is a social construct with regard to patterns of sexuality and behaviour imposed by cultural and social norms. However, the prevailing problem among many text consumers is the tendency to treat sex and gender as synonymous and hence their inability to see through the naturalised social standards of femininity or female gender in a patriarchal society. As such, the significance of this study is to demonstrate how female gendered roles and identities are learned and naturalised by patriarchy and women's compliance and negotiation with patriarchy with a view to asserting and validating their own identities. For a better understanding of such female gendered identities, the writer adopts a cross

Manuscript received June 9, 2017; revised September 10, 2017

Ong Cheng Teik is with the School of Education, Languages and Communications, Wawasan Open University, George Town, Penang, Malaysia (e-mail: egb789@hotmail.com-LC0008). disciplinary approach that borrows conceptual tools from various fields.

\section{ABout EMILY OF EMERALD HILL}

Written by award-winning playwright Stella Kon and directed by world renowned Malaysian director Chin San Sooi, Emily of Emerald Hill documents the vanishing tradition and culture of the Peranakan Chinese as depicted in the life story of the intriguing protagonist Emily, from her humble beginning to her rise as the matriarch of the affluent Gan family.

The monodrama was first staged in Seremban on 17 November 1984 to a full audience and favourable reception with actress Pearlly Chua playing Emily and it has since witnessed countless performances staged in various cities from Nantes to Paris, Edinburg, Honolulu, Sydney, Bangalore, Mumbai, Beijing, Hong Kong, Kuala Lumpur, Ipoh, Melaka, Johor Bahru, Kuching and Penang [1].

Numerous female performers have reprised the role of the matriarch Emily in this hugely successful and popular play more than 350 times in Singapore and overseas [2], the bulk of which is by Pearlly Chua with over 200 performances [1], Margaret Chan with over one hundred and three times and Malaysian born actress Leow Puay Tin with more than twenty one performances. It has also later spawns male / drag performance by actor Ivan Heng as Emily Gan in 2011 and musical adaptations in 2010, 2012, and 2016 [1]. More recently, its translation into and performances in other languages such as French, Icelandic, Hindi, Kannada, Japanese and Chinese further bear testimony to its resonance with an international audience.

Its local context and culture particular to this region does not hinder its universal appeal as observed by Talib: the play's "restricted local references are not a barrier to their international reception" [3]. Emily of Emerald Hill's international acclaim attests to its immense popularity that transcends geographical boundary, race, gender and culture.

Apart from providing a succinct insight into the Peranakan culture and a period of the history of Singapore and Malaysia, the drama strikes a universal cord of an individual struggling against an oppressive environment of social norms and patriarchy. The play tells the story of a thorough Nyonya (Peranakan Chinese lady) and formidable lady, Emily, who first arrived at the mansion of the Gan family as a child bride at the age of fourteen years old in 1929 . The many facets of her character gradually unfold from the multiple female roles she assumes that include but are not restricted to those of a capable domestic manager, a fond mother and a society hostess. Struggling to establish her 
position as the wife of the eldest son of the family in a patriarchal belief system prejudicial to women, the strong-minded Emily manages to overcome many trials and tribulations and eventually emerges triumphant as the matriarch of a large and distinguished household but at the expense of her son's suicide and her estrangement from her husband.

In short, Emily of Emerald Hill is not just the story of a woman, it is "the story of every woman of her generation who could only find power and fulfilment in the role of wife and mother" [1]. Such universal elements endear it to multicultural audiences who identify themselves with the multiple female roles Emily plays from a daughter to wife, daughter-in-law, girlfriend and mother [2].

\section{A Brief InTRODUCTION to the PERANAKAN CHINESE}

\section{A. Origins of the Peranakan People}

Variously known as Babas, Nyonyas, Bibiks, Straits Chinese and Straits-born Chinese, the Peranakan Chinese and their hybridised complex cultural identity are unique in Southeast Asia, with their origin dates back to the interracial marriages between immigrant Chinese men and non-Muslim women such as the Bataks, Balinese and Chitty from Malacca, Penang, Trengganu, Burma and Indonesia in the sixteenth century [4].

In concurrence with Lim [4], Chia posits that "the present-day Babas have long been believed to be the descendants of the unions of early Chinese immigrants to Malaya and indigenous Malay women" [5]. Since it is inconceivable that a Malay woman will marry a man outside her race and religion without first converting him to Islam, according to historian Sir Richard Winstedt (cited in [5]), the local wives of Chinese must have been pagan slaves from the Archipelago such as the Bataks from neighbouring Sumatra.

Today, the Peranakan community exists predominantly in Singapore, Malacca and Penang with the kinship ties extending to Indonesia and Phuket, Thailand where they are known as Indonesian Peranakan Chinese and Phuket Baba Chinese respectively [6]. As with other communities, it has embraced modernity, hence resulting in the simplification of elaborate traditions and the dwindling currency of Baba Malay.

According to Lim [4], strictly speaking, Peranakan is a Malay word that means 'local-born'. In order to differentiate them from the members of other locally-born races, the children of Chinese immigrants are referred to as Peranakan Chinese. However, it is a common practice among Singaporeans to refer to the Peranakan Chinese as just Peranakans or Babas. Their descendants married within the community, spoke mainly Baba Malay and English but little Chinese and adopted Malay attire such as the sarongs and culinary arts while retaining a number of Chinese customs adapted to the local practices. Chia succinctly sums up the Peranakan hybridised culture when he says that "it has been said that the Babas are Chinese in spirit and tradition but Malay in form" [5]. In concurrence, Tan refers to the Babas as “a localised community of acculturated Chinese” [6].

As such, the Baba Malay spoken by the Peranakans is punctuated with a considerable number of Hokkien (a Chinese dialect) words. However, not all Peranakan communities subscribe to the same practices with the Penang Babas being "considered as less acculturated, retaining a stronger Chinese culture especially in their language” [6]. Accordingly, Chua [7] considers the Baba identity to be defined along a cline instead of separate categories.

During the British rule in the Straits Settlements, the Peranakans grew in favour with the British subjects, hence building a rapport with the European colonists. Educated in English and consisted mostly of white-collar workers, the Peranakans adopted British working practices and lifestyles, so much so that many converted to Christianity and “... chose to submit their loyalty to the British” [6].

\section{B. The Peranakan People and Culture}

The practice of privileging sons over daughters was prevalent in the Peranakan culture as evident in Lim's account that 'in the early communities in Malacca, the boys were sent to schools to be educated. The girls, on the other hand, remained at their mother's side. Even when the Peranakans migrated to Singapore, this practice had not changed" [4].

Such patriarchal values and belief system were further entrenched in the Peranakan culture through the various socially constructed female gendered roles for women: "Once a girl turned twelve, her life of freedom ended. She would .... be instructed on the finer points of her future role as a respectable wife in a Peranakan family. She would pick up essential lessons in proper behaviour, cooking, sewing, embroidering, beadwork etc.” [4]. In short, a woman's place was confined within the house and we will see in subsequent sections that these socially constructed female roles are faithfully played out in Emily of Emerald Hill by the protagonist Emily.

On matters related to lifestyle, the Peranakans adopted the British way of life with ease, from working in British-owned companies to collecting ostentatious works of arts, decorating their homes in the European style, throwing dinner parties where British guests were invited and horse riding. It was not uncommon for wealthy Peranakan families to employ several domestic helpers to handle numerous household chores.

\section{CONSTRUCTION OF EMILY'S FEMALE IDENTITIES IN EMILY OF EMERALD HILL: CONCEPTUAL TOOLS}

Emily of Emerald Hill has become a site for the contestation of ideologies and discourses namely that between patriarchy and female empowerment. Central to this is the construction of Emily's female identities in the context of the Peranakan culture.

In this regard, the writer will adopt a cross disciplinary approach, borrowing conceptual tools from both the field of literature and non-literature such as sociology, philosophy and psychoanalysis with a view to analysing the construction of Emily's female identities. From the field of literature, the analysis is informed by post-structuralism whereas sociology provides the concept of female gendered identities and social construction of roles. In addition, the analysis is enriched by 
Lacan's notion of multiplicity and fluidity of identities from the psychoanalysis perspective and the philosophy of Confucianism. The adoption of a multiplicity of conceptual tools is in recognition of the fact that 'it is unlikely that any one theory can ever fully capture the complexity of human psychology and development' [8].

\section{A. Sociology}

According to sociolinguist Holmes, there are multiple roles that people play in their social networks where social network refers to "the pattern of informal relationships people are involved in on a regular basis" [9]. As such, people assume different roles and identities in their daily interactions with different people. These roles are socially constructed by the society or community as the dominant group dictates the norms and conventions to be observed by its members. In other words, "individuals perform particular aspects of their social identity in specific situations" [9] such as adopting a female gendered identity or a 'motherly' identity.

In the context of the play, the writer will examine the different roles and identities assumed by the protagonist Emily and how these roles are socially determined by her Peranakan culture and tradition. Of equal importance is an investigation of how Emily conforms to and negotiates with her socially constructed identities as Holmes succinctly puts it that "every time we speak (and act or behave), we either reinforce existing norms or we contest them” [9].

\section{B. Post-structuralism}

In the mid-1960s, both French philosopher Jacques Derrida and French cultural historian Michel Foucault (cited in [10]) postulated, among other key concepts, the non-existence of an objective reality or truth in their post-structuralist view of the world which is also variously and loosely known as deconstruction and post- modernism. In other words, there is no ultimate truth but many truths and realities. They regard all definitions and depictions of truth as subjective, depending on the various cultural and social influences in one's life. In connection to this, all truths are fully contextual and meaning is always changing. With regard to the concept of identity, it is a human construct that is open ended, in a constant state of flux and pluralistic. Such multiplicity and fluidity of human identities run parallel with the view of sociologists as mentioned earlier.

In relation to female identity, social constructs refer to patterns of female sexuality and behaviour imposed by cultural and social norms [8]. Just as "a human construct is shaped by each individual's dominant social group” [10], post-structuralist feminists are of the view that patriarchy imposes social standards of femininity on all biological women and naturalises these feminine standards [8].

Framing such post-structuralist view of multiplicity and fluidity of identities in general and female gendered identities in particular within the play, the writer attempts to examine how the protagonist Emily's words and actions, in her drive toward self-determination, undermine or reinforce male-centred definition and hierarchies in her Peranankan community.

\section{Confucianism}

As post-structuralists view the multiple female roles or identities as social constructs, it is necessary to discuss the prevailing social forces, beliefs and value system in Emily's Peranakan community that have an important bearing on such social constructs, namely those related to Confucianism.

Despite the fact that Emily and her family are of the Christian faith as evidenced from the line "the Bishop conducted a [funeral] ceremony [for Richard] at the family plot at Bidadari” [11], Confucianism as a philosophy is deeply rooted in the culture and belief system of both the Chinese and Peranakan Chinese.

In traditional Chinese society, Confucianism, along with its other teachings, upholds an oppressive patriarchal belief system that devalues women as they are rarely regarded as individuals in their own right [12]. Apart from submissiveness, dependence and self-sacrifice as pre-requisite qualities of womanhood, the basic Confucian maxim emphasises the three obediences and four virtues of a model woman which privilege the male. Disobeying the male is tantamount to disrespecting the traditional teachings which upholds patriarchy [13]. Such subordination echoes traces of patriarchy which considers women as "less privileged" [14], a sign that is indicative of unequal gender treatment.

In a Confucian society, men are considered far more superior than women as evident in the privileging of sons over daughters in such matters as inheritance and ancestor worship. In the olden days, in order to perpetuate male superiority over women, women were denied education and hence made dependent on their husbands. As such, women were mostly confined to the domestic sphere of being a submissive and obedient wife.

Such Confucian patriarchal practices are evidently present in the play in the treatment of Emily's mother and husband toward her. For instance, Emily's mother abandoned her at the age of ten years old after her father's death. Her mother lamented that "Why am I so unlucky? I don't have a son to take care of me. I only have a useless daughter like you. What were you born for?” [11]. This statement reveals the privileging of sons over daughters and it is ironic to note that it is Emily's very own mother who helps to perpetuate such unjust patriarchal practice. This is an insidious manifestation of patriarchy that perpetuates "a vicious cycle where women have become active agents of oppression while patriarchy sets the platform for subtle designs of men.” [15]. Kourany et al. [16] attribute such ironic phenomenon of women themselves enforcing patriarchal practices to the fact that the prevalence of patriarchy had entrenched these practices in their consciousness since childhood.

\section{Psychoanalysis}

A cursory discussion of psychoanalysis serves to bridge an important gap between Emily's multiple socially constructed female identities and her desire for female empowerment through her constant negotiation with Confucian patriarchal belief system as it provides the readers with Emily's psychological make-up and her motivations in her life, hence giving readers a better understanding of what makes the protagonist tick. In other words, psychoanalysis, in the context of this play, elucidates how patriarchy dictates power relations between men and women [17].

In concurrence with the post-structuralist view that our sex is biologically determined but "our gender or our 
sexuality ..... is culturally created" (Lacan, cited in [10]), the crux of French neo-Freudian psychologist Jacques Lacan's (cited in [10]) theory and his understanding of the human psyche hinge on the notion of lack and fragmentation or the divided self. Such fragmentation is attributed to our unfulfilled longings for love, for physical pleasure and our desire to return to and be at one with our mother. This is evident in Emily's childhood when she was abandoned by her mother at the age of ten years old after her father's death.

Both psychologists Freud and Lacan also recognise that "individuals move through developmental stages early in life and traumas or experiences during that process may have a lasting effect on personality” (Freud and Lacan, cited in [8]). In relation to Emily's situation, the following quotation may provide a useful glimpse of or a profound insight into her psychological make-up which in turn is instrumental in the understanding of her prime motivation for her behaviour and outlook on life: “.... you have no value, except as you are a wife and mother: then be the very devil of a wife and mother .... so that a screaming girl-child, long ago, may be reassured that her life has some significance...” [11].

The quote also provides a useful revelation about several aspects of Emily's life namely her fear of not being loved again, her conformity to the female gendered identities and roles prescribed to her by the unjust Confucian patriarchal belief system and her own female empowerment through her negotiation with patriarchy by cleverly making all her family members dependent on her.

In relation to fragmentation of the self, Lacan further posits that our identities are not fixed but change with different constraints of our environment according to the multiple roles and identities we assume. As such, our identities are in a constant state of flux through our interaction with others and these changes and transformations in identities are worth examining compared to fixed or binaristic identities.

In the context of the play, we can chart Emily's self-transformation in her life from an unfortunate and abandoned orphan and powerless young wife to a self-determined and domineering wife and matriarch as well as from a suffocatingly overprotective and overbearing mother to a caring and understanding mother and grandmother. All these transformations are effected by the bitter lessons that she learns as she journeys through her life.

\section{ANALYSIS OF THE CONSTRUCTION OF EMILY'S FEMALE IDENTITIES IN EMILY OF EMERALD HILL}

Employing a multiplicity of conceptual tools mentioned in the previous section, the writer will attempt to excavate the various dominant discourses in the play, mainly those related to Confucian patriarchy. This serves to examine how Emily dialogues with these discourses in her struggle to construct her female identities and roles, mainly those of an obedient daughter, a filial daughter-in-law, a dutiful wife and a loving mother.

\section{A. The Role of a Daughter}

As a victim of Confucian patriarchy, Emily was abandoned by her mother at the young and vulnerable age of ten years old after her father's death and she was subsequently trusted to the care of one relative after another until she was married off at the age of fourteen years old to her cousin twice her age. Her mother's abandonment of her is largely due to the prevailing practice of privileging of sons over daughters as evident in the following line uttered by Emily's mother: "Why am I so unlucky? I don't have a son to take care of me. I only have a useless daughter like you. What were you born for?” [11].

Emily's arranged marriage to her cousin when she was only fourteen years old underscores the powerless position women occupy in her society and the fact that daughters are perceived as a burden to the family. This is not uncommon in the Confucian patriarchal system that sees many women being sold as house-maids or prostitutes by their families for financial gain as women are considered a burden to their families [18].

Emily comes to grip with the harsh reality and accepts the powerless station she is in. Such realisation is to subsequently shape Emily's philosophy of life as she plays out the various female roles ascribed to her, from a dutiful wife to an obedient daughter-in-law and a loving mother. Her traumatic childhood experience has taught her the bitter lesson that the only way she can negotiate with patriarchy and assert her power subtly is through playing her roles well in the domestic sphere. These are the exact roles dictated by patriarchy under which women are led to believe that marriage and motherhood is "a woman's entire destiny and the fulfillment of her nature” [19].

\section{B. The Role of a Daughter-in-law}

As Emily steps foot into the Gan mansion and assumes her new role as daughter-in-law, she comes to the realisation of the roles expected of her by the wealthy Gan family namely grateful, humble and obedient, roles that Emily is to play very well to her own advantage. As such, she goes to great length to get in her father-in-law and mother-in-law's good books. For instance, Emily strategises to win her mother-in-law over by making tea and sireh (betel leaves), waiting on her and giving her tombok (massage) during her cards sessions. Her effort pays off when her mother-in-law rewards her with a big diamond ring.

Furthermore, God seems to be on Emily's side when she gives birth to Richard, the first son of the eldest son (i.e. Kheong, Emily's husband) in the Gan family, hence endearing her to her father and mother-in-law and making them happy as grandsons are privileged over granddaughters in patriarchy. This is very much in conformity to patriarchy that expects a daughter-in-law to serve her in-laws and to provide a son as an heir who will maintain the family line [13].

Emily emerges triumphant eventually as she has achieved her twin goals of gaining her father and mother-in-law's approval and asserting and validating her position as the wife of the eldest son. In her negotiation with patriarchy and tradition, the irony lies in Emily's very insistence on observing tradition that contributes to her female empowerment. Emily has no difficulty in securing the largest share of the property, including the mansion Emerald Hill, for her eldest son Richard when her father-in-law dies in line 
with his wish for the estate to stay in one piece until the next generation. This episode is another evidence of the patriarchal practice of privileging of sons over daughters.

\section{The Role of a Wife}

Emily accepts her woeful fate as she realises that marriage is her only ticket out of the gutter and to gaining recognition, validation and legitimation of her identities. As Warren [18] observes, the Chinese patriarchal system has robbed women of their identities within their family and the community. Such loss of identities is evident as Chinese women are identified in terms of their relation to men such as mother to her son: "They live the life of an outsider ... and this essentially is due to cultural and religious beliefs" [18]. As such, marriage provides these women with a sense of security and importance within the family unit [19].

Knowing that one of the duties of a wife is to produce children, Emily bears Kheong three sons and a daughter namely Richard, Edward, Charlie and Doris. This must have brought tremendous joy to both her husband and her father and mother-in-law as sons are favoured over daughters in patriarchy. In addition, it also elevates Emily's status in her family and society as she manages to sire sons for the family.

The events in her life take a turn for the worse when her husband leaves her to stay with his mistress Diana Lee at her house in Amber Road. Being a strict upholder of Confucian patriarchal norms and values, Emily plays the role of a traditional wife suffering in silence. Emily has no choice but to suffer in silence since the alternative of divorce is unimaginable as a divorced woman carries with her a social stigma and marriage is the only way for Emily to gain respect, recognition and legitimacy of her female identities. Such obedience is reflective of traditional Confucian beliefs that demand "total obedience of women to their husbands, father, mother-in-law and finally their son...” [15]. As such, Emily resorted to silence as a strategy to handle oppression (Laurence, cited in [20]).

By living up to her patriarchally constructed female role of an obedient, submissive and enduring wife, Emily is resorting to the only avenue left to her to maintain her dignity and honour in the face of hostility, trials and tribulations. True to the tradition of patriarchy, she remains a virtuous, loyal and faithful wife until the very end.

\section{The Role of a Mother}

Emily takes comfort and pride in playing her role of a caring mother to her four children, in particular to her favourite eldest son Richard, as motherhood is the only domain which she can exert her influence on her children: "Your life is meaningless, you have no value, except as you are a .... mother: then be the very devil of a .... mother .... so that .... [they] must all depend on you .... So that the whole world knows your worth ....” [11].

Emily is determined to be a protective mother to her children, so much so that they will forever be dependent on her as she sees this as her only way to exert power and control over them. However, her overzealous effort to be an overprotective mother results in the tragic death of her eldest son Richard, a tragic event that marks the emergence of a kinder and more understanding mother in Emily in her subsequent treatment of her other children, especially Doris.
This is in line with a realistic portrayal of a multidimensional (instead of binaristic and fixed) character whose fluid identity is in constant flux as a result of her interactions or dialogues with other characters.

Being the eldest son, Richard is Emily's pride and joy and she showers him with all her attention and care that borders to suffocation and overprotectiveness. However, such overprotectiveness bears undesirable results as once Richard is free from the shackles of his mother's control in England, he neglects his studies, leaves his university and ends up working as an instructor at Mr. Green's riding school at Salisbury. In his letter to Emily, he expresses his refusal to comply with her wishes and plans for him which prompts Emily to go to London immediately and reprimands him for being ungrateful and disappointing her. This shows that motherhood provides Emily with the only avenue to yield her control and power over her children, a manifestation that leads to Richard's suicide in her attempt to impose her dreams on Richard instead of understanding and accommodating his wishes. This can also be considered as a form of oppression under patriarchy that Emily perpetuates subconsciously: “... filial piety, another key element of the patriarchy system, plays a major role for mothers oppressing their children” [15].

The loss of her eldest son has made her come to the realisation that the only way for her to win her children's hearts is through care and understanding. This is evident in Emily's reaction to her daughter Doris when she informs Emily of her intention to marry Steve Jackson, a Caucasian, in America. Afraid of alienating and losing Doris the way she loses Richard, instead of forbidding her, Emily has finally learned not to impose her power and control over her children's lives.

On a separate matter, having internalised the norms and values of patriarchy, Emily unknowingly perpetuates the practice of favouring sons over daughters by presenting a much gendered female identity to Doris: "Doris, stop reading. What, this girl forever has her nose in a book. Come and help me in the kitchen, when you are married you must know how to cook and look after your family” [11]. This underscores the irony that not only men but also women in a patriarchal society that enable women's own subjugation. As Ramdas, Shakila and Sabapathy aptly put it, “...women, acknowledging the patriarchal settings, play the role of agents of oppression” [15].

\section{CONCLUSION}

This paper is an attempt to show that within the confines of the Confucian patriarchal belief system, Emily assumes a multiplicity of socially constructed female identities and roles demanded of her and at the same time constantly engages in a dialogic relationship with patriarchy with a view to creating space for her to assert her own female identities.

Her eventual rise from a poor abandoned orphan girl to the matriarch of the affluent Gan family bears testimony to her triumphant effort in negotiating patriarchy instead of confronting it or resigning herself to her fate by accepting her subjugated and subservient status. Through Emily's portrayal of multiple and conflicting female roles, Kon highlights the 
paradox and irony of Emily's female empowerment as in the process of negotiating with patriarchy, Emily subconsciously perpetuates some patriarchal practices in her treatment of her family members. Such multifaceted and multidimensional character only serves to add depth to a realistic portrayal of Emily, warts and all.

\section{REFERENCES}

[1] S. Kon. Emily of Emerald hill. [Online]. Available: http://www.emilyofemeraldhill.com/

[2] C. Kriplani. (2013). Emily of Emerald hill: A reaffirmation of Peranakan culture. Education about Asia, Asian Visual and Performing Arts, [Online]. Part II, 18(1), pp. 1-5. Available: http://208.75.20.218/EAA/18-1-Supplemental/kripilani_18-1.pdf

[3] I. S. Talib, "Malaysia and Singapore," The Journal of Commonwealth Literature, vol. 51, no. 4, pp. 617-630, 2016.

[4] G. S. C. Lim, Gateway to Peranakan Culture, Singapore: Asiapac Books Pte Ltd., 2004, pp. 1-63.

[5] F. Chia, The Baba, Singapore: Times Books International, 1980, pp. 7-39.

[6] B. Tan, "Textualising the Baba identity: Insights into the making of a bibliography,” in Reframing Singapore: Memory, Identity, Trans-regionalism, D. Thiam and S. Aljunied, Eds. Amsterdam: Amsterdam University Press, 2009, pp. 133-154.

[7] A. L. Chua, "Negotiating national identity: The English-speaking domiciled communities in Singapore, 1930-41,” M.S. Thesis. Singapore: National University of Singapore, 2001.

[8] D. E. Hall, Literary and Cultural Theory: From Basic Principles to Advanced Applications, Boston: Houghton Mifflin Company, 2001, pp. 103-134; pp. 16-232.

[9] J. Holmes, An Introduction to Sociolinguistics, 4th ed., Oxon: Routledge, 2013.

[10] C. E. Bressler, Literary Criticism: An Introduction to Theory and Practice, 2nd ed., New Jersey: Prentice-Hall Inc., 1999, pp. 114-177.

[11] S. Kon, Emily of Emerald Hill: A Monodrama, London: Macmillan Publishers, 1989.
[12] A. M. Shakila, "Culture, gender and identity: Reading Che Husna Azhari's Melor in Perspective and Suchen Christine Lim's Gift from the Gods," presented at the International Seminar on Southeast Asian Women Writers, Kuala Lumpur, Malaysia, September 7-8, 2004.

[13] E. Croll, Feminism and Socialism in China, London: Routledge \& Kegan Paul, 1978.

[14] P. M. Lengermann and J. Niebrugge, "Chapter 12: Contemporary feminist theory,” in Sociological, G. Ritzer, Ed. New York, NY: McGraw-Hill, 1996.

[15] S. M. Ramdas, A. M. Shakila, and E. Sabapathy, "Resistance and oppression in Su-Chen Christine Lim's novels: A radical feminist analysis," Studies in Literature and Language, vol. 1, no. 7, pp. 89-97, 2010.

[16] J. Kourany, J. P. Sterba, and R. Tong, Feminist Philosophies, Boston: Prentice Hall, 1999.

[17] J. Stacey, “Untangling feminist theory," in Introducing Women's Studies, D. Richardson and V. Robinson, Eds. London: Macmillan, 1993, p. 53.

[18] K. J. Warren, "A feminist philosophical perspective on ecofeminist spiritualities," in Ecofeminism and the Sacred, C. J. Adams, Ed. New York: Continuum, 1993.

[19] B. Kreps, "Radical feminism 1," in Feminist Theory Reader: Local and Global Perspectives, C. R. McCann and S. K. Kim, Eds. New York: Routledge, 2003, pp. 45-49.

[20] E. Hedges and S. F. Fishkin, Listening to Silences: New Essays in Feminist Criticism, New York: Oxford University Press, 1994.

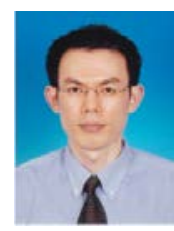

Ong Cheng Teik is a senior lecturer with the School of Education, Languages and Communications at Wawasan Open University, Penang, Malaysia. He holds a bachelor of education (Hons) majoring in TESL from Universiti Malaya and a master of arts (linguistics and English language studies) from Universiti Sains Malaysia. He has taught a range of courses at certificate, diploma, degree and post-graduate diploma levels, some of which are digital newsletter, online journalism, pedagogical grammar of English, communication skills for teachers and academic discourse skills. His areas of research interest are grammar, code-switching and critical discourse analysis. 